\title{
Hubungan Antara Harga Diri dengan Pengambilan Keputusan untuk Kawin pada Wanita Bali Usia Dewasa Awal
}

Anak Agung Ketut Sri Wiraswati dan Supriyadi

Program Studi Psikologi, Fakultas Kedokteran, Universitas Udayana gswiraswati@gmail.com

\begin{abstract}
Abstrak
Individu usia dewasa awal memiliki kebutuhan untuk mengembangkan hubungan intim, salah satunya dengan jalan perkawinan (Santrock, 2002). Sebelum memutuskan melangsungkan perkawinan, individu melakukan serangkaian kegiatan pengambilan keputusan. Harga diri adalah salah satu variabel yang terkait dalam pengambilan keputusan yang dilakukan individu, khususnya dalam mengambil keputusan untuk kawin. Tujuan utama penelitian ini adalah untuk mengetahui arah dan kekuatan hubungan antara harga diri dengan pengambilan keputusan untuk kawin pada wanita Bali usia dewasa awal.

Sebanyak 196 wanita Bali berusia antara 20 hingga 40 tahun dan berstatus kawin menjadi responden dalam penelitian kuantitatif korelasional ini. Teknik sampling yang digunakan adalah two stage cluster sampling. Alat ukur yang digunakan adalah skala harga diri $(27$ aitem; rxx` $=0,883)$ dan skala pengambilan keputusan untuk kawin $(16$ aitem; rxx`=0,824).

Data diolah dengan analisis Pearson Product Moment, regresi linear sederhana, dan one-way ANOVA. Hasil analisis statistik menunjukkan ada hubungan antara harga diri dengan pengambilan keputusan untuk kawin $(r=0,723 ; p=$ 0,000). Koefisien determinasi diperoleh sebesar 0,523 yang berarti 52,3\% varians yang terjadi pada variabel pengambilan keputusan untuk kawin dapat dijelaskan oleh varians pada variabel harga diri. Analisis uji $\mathrm{F}$ menemukan bahwa mean skor variabel pengambilan keputusan untuk kawin tidak berbeda secara signifikan apabila dikaji dari tingkat pendidikan $(\mathrm{F}=1,169 ; \mathrm{p}=0,323)$ dan urutan kelahiran $(\mathrm{F}=0,601 ; \mathrm{p}=0,550)$.
\end{abstract}

Kata kunci: Harga diri, pengambilan keputusan untuk kawin, wanita Bali, usia dewasa awal.

\begin{abstract}
Early adulthood have a need to develop an intimate relationship through marriage (Santrock, 2002). Before deciding to hold the marriage, they conducted a series of decision-making process. Self-esteem is one of the variables that involved in individual decision-making. The main purpose of this study is to investigate the direction and strength of relationship between self-esteem and decision-making to get married among early adulthood Balinese women.

A total of 196 Balinese women aged between 20 up to 40 years old and married becoming the subject of this quantitative correlational research. The sampling technique was two-stage cluster sampling. Measuring instruments used are the self-esteem scale $\left(27\right.$ items; $\left.\mathrm{rxx}^{`}=0,883\right)$ and decision-making to get married scale $\left(16\right.$ items; $\mathrm{rxx}^{`}=$ $0,824)$.

Data were processed using Pearson Product Moment analysis, simple linear regression, and one-way ANOVA analysis. Statistical analysis show, there is significant correlation between self-esteem and decision-making to get married among early adulthood Balinese women $(r=0,723 ; \mathrm{p}=0,000)$. The coefficient of determination obtained for 0,523 which means that $52,3 \%$ of the variance that occurs in the decision-making to get married variable can be explained by the variance in self-esteem variable. $\mathrm{F}$ test analysis found that the mean scores for decision-making to get married did not differ significantly when assessed from the level of education $(\mathrm{F}=1,169 ; \mathrm{p}=0,323)$ and birth $\operatorname{order}(\mathrm{F}=0,601 ; \mathrm{p}=0,550)$.
\end{abstract}

Keywords: Self-esteem, decision-making to get married, Balinese women, early adulthood 


\section{LATAR BELAKANG}

Manusia merupakan makhluk ciptaan Tuhan dengan kompleksitas tertinggi diantara makhluk ciptaanNya yang lain. Sebagai makhluk sosial dan merujuk pada konsep Tri Hita Karana, manusia diharapkan menjalin hubungan harmonis dengan Tuhan, lingkungan dan sesama manusia lainnya dengan tujuan untuk memperoleh kesejahteraan, kedamaian dan kebahagiaan dalam kehidupan (Pemerintah Daerah Provinsi Bali, 2009).

Semua individu memiliki kebutuhan bawaan untuk menjalin hubungan intim, yang merupakan komponen inti dari kehidupan (Jeter, 2002). Usia dewasa awal merupakan masa krisis perkembangan psikososial intimacy versus isolation. Pada tahap krisis perkembangan ini, individu usia dewasa awal (20-40 tahun) membutuhkan pemuasan kebutuhan akan intimasi yang dapat diperoleh dari menjalin hubungan dengan individu lain, sehingga menekankan pada relasi harmonis antar sesama manusia (Erikson dalam Papalia, Olds, \& Feldman, 2009).

Selain mengalami krisis perkembangan psikososial, individu pada usia dewasa awal memiliki tugas sosioemosional untuk tergabung menjadi anggota keluarga melalui jalan perkawinan (Santrock, 2002). Individu usia dewasa awal memiliki tugas perkembangan untuk memperoleh pekerjaan, mendapatkan pasangan hidup, menjalani kehidupan rumah tangga dengan suami atau istri, membentuk suatu keluarga, membesarkan dan mendidik anak, bertanggung jawab sebagai warga negara, dan tergabung dalam kelompok sosial yang sesuai (Hurlock, 1980).

Perkawinan menjadi hal yang penting dalam kehidupan individu usia dewasa awal (Anissa \& Handayani, 2012). Perkawinan menjadi salah satu sumber stres yang cukup mempengaruhi hidup individu usia dewasa awal (Huffman, Vernoy, Williams, \& Vernoy, 1991). Adapun beberapa alasan indivdu melangsungkan perkawinan, yaitu persahabatan, cinta kasih dan intimasi, hubungan saling mendukung dengan pasangan, hubungan untuk berinteraksi secara seksual, berbagi peran sebagai orangtua, kehamilan, pemberontakan, mencari kebebasan, pelarian dari hubungan sebelumnya, tekanan dari keluarga, dan jaminan ekonomi (Olson \& DeFrain, 2003). Pasangan yang memilih kawin mengharapkan memperoleh kebahagiaan dalam perkawinan yang dibina, namun dalam kurun waktu tertentu pasangan akan menemukan fakta bahwa kehidupan perkawinan tidak selalu indah dengan kemunculan konflik.

Sadarjoen (2005) mengungkapkan bahwa kehidupan perkawinan tidak dapat lepas dari konflik dan tantangan. Perkawinan membuka jalan bagi interaksi yang lebih sering dan dekat antara keluarga suami dengan wanita yang berperan sebagai istri. Interaksi antara wanita dengan keluarga suami, tidak hanya berlangsung dalam waktu yang singkat, tetapi akan terus berkesinambungan sepanjang hidup bersama dengan institusi lain selain keluarga (Susilastuti dalam Anissa \& Handayani, 2012). Wanita yang telah resmi kawin dalam budaya yang menganut garis keturunan patrilineal akan tinggal bersama suami dan menjadi anggota baru dalam keluarga suami (Panetje dalam Kurniawati, 2009)

Apabila membicarakan mengenai perkawinan, perkawinan tidak dapat dilepaskan dari isu budaya (Jeter, 2002; Matsumoto \& Juang, 2008; Meinarno, Widianto, \& Halida, 2011). Pada masyarakat Bali yang menerapkan konsep Tri Hita Karana sebagai dasar menjalani kehidupan, perkawinan merupakan bagian dari usaha menjaga hubungan baik antar sesama manusia. Perkawinan dalam masyarakat Bali menganut sistem kekeluargaan patrilineal (Windia dkk., 2009). Sistem kekeluargaan patrilineal yang dimaksud yaitu hubungan seorang anak dengan keluarga ayah menjadi dasar tunggal bagi susunan sebuah keluarga. Keluarga dari garis ayah atau dari garis purusa (laki-laki) lebih diutamakan daripada keluarga dari garis keturunan ibu. Penerapan konsep purusa juga terjadi dalam perkawinan, ketika seorang wanita sudah kawin, maka wanita akan tinggal di rumah keluarga suami. Pada saat yang sama, wanita akan resmi mohon diri dari pura keluarga asal dan melaporkan diri sebagai anggota keluarga baru di pura keluarga suami. Setelah wanita resmi bergabung dalam keluarga suami, maka wanita akan memiliki kewajiban untuk lebih memuliakan pura keluarga suami, dan keluarga dari pihak suami. Wanita tidak dilarang untuk memuliakan keluarga asal, namun hal itu boleh dilakukan setelah wanita terlebih dahulu memenuhi tanggung jawab di dalam keluarga suami. Sistem kekeluargaan patrilineal, juga mengatur status anak yang lahir dalam sebuah perkawinan. Anak yang lahir dari perkawinan akan ikut masuk ke dalam garis keturunan ayah (Panetje dalam Kurniawati, 2009).

Membina keluarga melalui jalan perkawinan menjadi pilihan dari sebagian besar masyarakat Bali yang berjenis kelamin wanita. Sebagian besar wanita Bali memilih perkawinan sebagai jalan untuk membangun keluarga dapat dilihat dari hasil pendataan statistik demografi dan sosial ekonomi rumah tangga Provinsi Bali tahun 2011, yang mencatat sebanyak 53,09\% penduduk provinsi Bali berjenis kelamin perempuan berstatus kawin (Putrawan \& Sari, 2011). Pengambilan keputusan untuk kawin menjadi isu penting mengingat pendapat Sarwono (2006) yang mengungkapan bahwa di Indonesia, wanita rentan menerima prasangka negatif seperti dijuluki "perawan tua" apabila belum kawin pada usia diatas 30 tahun.

Dewasa ini, perkawinan dianggap sebagai pilihan dan keputusan dari individu yang bersangkutan (Peck, 1993; Matsumoto \& Juang, 2008). Apabila dilihat dari penerapan sistem kekeluargaan patrilineal pada masyarakat Bali yang hingga kini masih dominan, menimbulkan beberapa implikasi khususnya dalam hal pengambilan keputusan melakukan perkawinan (Atmaja, 2008). Seiring perkembangan jaman, kini romantisme menjadi dasar dalam memilih pasangan 
Individu memilih sendiri pasangan hidup dan menentukan keputusan yang diambil untuk melanjutkan hubungan yang dibina bersama pasangan (Taylor, Peplau, \& Sears, 2009). Keberhasilan individu untuk merasa mampu menghadapi tantangan dalam kehidupan melibatkan komponen harga diri. Menurut Blanchard-Fields (dalam Gayer, 2013), individu yang memiliki harga diri yang tinggi, percaya pada kemampuan yang dimiliki untuk membuat keputusan dan bertanggungjawab terhadap keputusan yang dibuat, sehingga individu yang memiliki harga diri yang tinggi cenderung menggunakan sumber daya internal yang ada dalam diri untuk membuat suatu keputusan, daripada melibatkan individu lain untuk membuat keputusan.

Pengambilan keputusan adalah suatu proses kognitif yang tidak tergesa-gesa, terdiri dari rangkaian tahapan yang dapat dianalisa, diperhalus, dan dipadukan untuk menghasilkan ketepatan serta ketelitian yang lebih besar dalam menyelesaikan masalah dan memulai tindakan (Gullies dalam Mandei, 2010). Pengambilan keputusan terdiri dari empat aspek yaitu hasil yang diharapkan, aktivitas yang dilakukan, kompetensi untuk melakukan, dan evaluasi (Huber dalam Kasim, 1989). Menurut beberapa tokoh, dalam pengambilan keputusan, individu dapat dipengaruhi oleh faktor sikap, kepribadian, intelegensi, urutan kelahiran, bakat, minat, aspirasi dan pengetahuan sekolah, kelompok primer dan kelompok sekunder (Sukardi, 2004); efikasi diri, kepercayaan diri, dan budaya (Wolfe \& Betz, 2004); emosi, kesanggupan, tuntutan orangtua atau keluarga, dan pengalaman (Gunarsa \& Gunarsa, 1995).

Setiap kegiatan pengambilan keputusan mengandung perilaku berani mengambil risiko (risk taking behavior) terkait dengan kesiapan menanggung konsekuensi yang mungkin muncul apabila mengambil suatu keputusan (Atmosudirjo, 1984; Yates, 1994; Manullang, 1994; Supranto, 1998). Brockner, Wiesenfeld, dan Raskas (dalam Wray \& Stone, 2005) mengungkapkan bahwa individu dengan harga diri yang rendah cenderung melindungi diri secara berlebihan dengan meminimalisir hal buruk terjadi pada diri, sehingga menjadi terlalu takut untuk membuat suatu keputusan. Sedangkan individu dengan harga diri yang tinggi cenderung berani mengambil keputusan yang berisiko. Harga diri adalah variabel yang penting untuk dipertimbangkan dalam kegiatan pengambilan keputusan yang bersifat personal karena setelah mengambil suatu keputusan terdapat potensi keputusan akan mengalami kegagalan atau penolakan (Wray \& Stone, 2005). Menurut Branden (1995), harga diri tersusun dari enam aspek yaitu menjalani kehidupan dengan penuh kesadaran, penerimaan diri, bertanggungjawab pada diri, asertif, menjalani hidup berbasis tujuan, dan memiliki integritas.

Pada masyarakat dengan budaya kolektivis, pendapat individu lain di sekitar sangat mempengaruhi penilaian individu terhadap diri sendiri (Tafarodi \& Walters, 1999).
Individu yang berasal dari budaya kolektivis cenderung memiliki harga diri yang lebih rendah apabila dibandingkan dengan individu yang berasal dari budaya individualis (Tafarodi \& Walters, 1999; Farruggia, Chen, Greenberger, Dmitrieva, \& Macek, 2004; Konrath, 2012). Masyarakat Bali merupakan salah satu kelompok masyarakat yang hidup dalam budaya kolektivis. Komponen harga diri terlibat dalam kegiatan pengambilan keputusan yang dilakukan oleh individu. Harga diri tinggi diprediksi berkorelasi positif dengan pengambilan keputusan yang bersifat adaptif. Sementara harga diri rendah diprediksi memiliki korelasi negatif dengan pengambilan keputusan yang bersifat maladaptif (Commendador, 2007; Amalor dalam Ramanigopal, 2008; Ramanigopal, 2008). Individu dengan harga diri yang tinggi cenderung membuat keputusan dengan lebih baik karena berusaha menemukan lebih banyak informasi, mencari lebih banyak pilihan alternatif, dan mempertimbangkan dengan lebih seksama setiap konsekuensi yang menyertai alternatif pilihan yang ada (Ramanigopal, 2008). Selain itu, individu dengan harga diri yang tinggi cenderung dapat membuat keputusan dengan baik karena individu juga memiliki kepercayaan pada kemampuan diri sendiri (Prayor \& Smith; Mann, Beswick, Allouache, \& Ivey dalam Ramanigopal, 2008).

Sebelum individu merasakan kehidupan perkawinan, tentu terlebih dahulu akan melewati tahap pengambilan keputusan untuk kawin. Pada beberapa penelitian sebelumnya, diketahui bahwa harga diri berhubungan dengan kegiatan pengambilan keputusan yang dilakukan oleh individu. Namun tingkat harga diri pada individu dari budaya kolektivis ditengarai lebih rendah dari pada individu yang berasal dari budaya individualis. Sementara, masyarakat Bali merupakan salah satu kelompok yang berasal dari budaya kolektivis, dan sebagian besar masyarakat Bali berjenis kelamin perempuan berstatus kawin.

Penelitian ini bertujuan untuk mengetahui arah dan kekuatan hubungan antara harga diri dengan pengambilan keputusan untuk kawin pada wanita Bali usia dewasa awal, Menghitung besaran variasi pada variabel harga diri untuk menjelaskan variasi yang terjadi pada variabel pengambilan keputusan untuk kawin, melihat perbedaan rata-rata nilai pengambilan keputusan untuk kawin berdasarkan tingkat pendidikan dan urutan kelahiran, serta mengungkap alasan melangsungkan perkawinan dan alasan dibalik kepuasan perkawinan responden.

Hasil penelitian ini diharapkan dapat menambah kajian di bidang psikologi wanita dan psikologi perkembangan keluarga, serta dapat menjadi referensi bagi individu atau kelompok yang hendak melaksanakan kegiatan penyuluhan dan konseling tentang perkawinan, pelatihan pengambilan keputusan, menjadi sumber informasi bagi wanita Bali yang hendak mengambil keputusan untuk kawin, dan kaitannya 
dengan harga diri dari sudut kajian psikologi, serta data hasil penelitian dapat menjadi acuan bagi penelitian selanjutnya.

Berdasarkan uraian latar belakang, maka dapat diajukan hipotesis yaitu terdapat hubungan positif yang signifikan antara harga diri dengan pengambilan keputusan kawin pada wanita Bali usia dewasa awal.

\section{METODE}

\section{Variabel dan definisi operasional}

Definisi operasional variabel penelitian merupakan bagian yang mendefinisikan sebuah konsep atau variabel agar dapat diukur dengan cara melihat pada indikator dari suatu konsep atau variabel tertentu (Noor, 2011). Dalam penelitian ini terdapat variabel bebas yaitu harga diri, dan variabel tergantung yaitu pengambilan keputusan untuk kawin.

Definisi operasional variabel harga diri adalah evaluasi yang diberikan oleh individu pada dirinya sendiri tentang kompetensi diri, keberhargaan diri, serta penghormatan terhadap nilai-nilai pribadi yang dianut.

Konsep harga diri diukur menggunakan skala harga diri yang disusun oleh peneliti berbentuk skala Likert berdasarkan enam aspek harga diri menurut Branden (1995), yaitu menjalani kehidupan dengan penuh kesadaran, penerimaan diri, bertanggungjawab pada diri, asertif, menjalani hidup berbasis tujuan, dan memiliki integritas.

Sementara definisi operasional variabel pengambilan keputusan untuk kawin dalam penelitian ini adalah penentuan komitmen memilih melaksanakan perkawinan sebagai wadah untuk hidup bersama dari serangkaian alternatif pilihan yang mungkin dilakukan dengan tujuan untuk menyelesaikan masalah dan mencapai hasil yang sesuai dengan harapan.

Konsep pengambilan keputusan untuk kawin diukur menggunakan skala yang disusun oleh peneliti berbentuk skala Likert berdasarkan aspek pengambilan keputusan menurut Huber (dalam Kasim, 1989) yaitu hasil yang diharapkan, aktivitas yang dilakukan, kompetensi untuk melakukan, dan evaluasi.

\section{Karakteristik responden}

Populasi dalam penelitian ini adalah wanita suku Bali usia dewasa awal. Pengambilan sampel dalam penelitian ini ditentukan oleh peneliti berdasarkan beberapa kriteria tertentu. Adapun kriteria inklusi responden penelitian ini adalah wanita keturunan suku Bali yaitu wanita yang berasal dari orangtua dan keluarga yang merupakan keturunan suku Bali, serta melangsungkan perkawinan dengan laki-laki yang juga merupakan keturunan suku Bali; berusia antara 20-40 tahun; dan berstatus kawin.
Teknik sampling yang digunakan dalam penelitian ini adalah two stage cluster sampling. Menurut Nazir (1988), pada tahap pertama dilakukan pemilihan primary sampling unit dari total primary sampling unit. Pada tahap kedua dilakukan pemilihan unit elementer dari unit elementer yang ada dalam primary sampling unit yang sudah terpilih sebelumnya. Pada penelitian ini, daerah populasi adalah Provinsi Bali. Pada pemilihan tahap pertama menghasilkan Kota Denpasar sebagai primary sampling unit. Pada tahap kedua, menghasilkan Kecamatan Denpasar Barat sebagai unit elementer dari Kota Denpasar yang akan dijadikan cluster penelitian. Rumus penentuan jumlah sampel yang digunakan adalah rumus menurut Hague dan Haris (1995), sehingga diperoleh jumlah sampel minimum dalam penelitian ini adalah 184 orang.

\section{Tempat penelitian}

Berdasarkan teknik pengambilan sampel yaitu two stage cluster sampling, maka ditentukan penelitian ini dilakukan di Kecamatan Denpasar Barat sebagai area sampling. Peneliti menyebarkan skala ke instansi, maupun datang langsung ke rumah-rumah warga dan memberikan skala kepada individu yang memiliki karakteristik sesuai dengan kriteria responden penelitian di wilayah Kecamatan Denpasar Barat

\section{Alat Ukur}

Skala yang digunakan dalam penelitian ini merupakan skala yang disusun oleh peneliti dengan menggunakan model skala Likert. Aitem dalam skala telah melewati uji validitas dan reliabilitas. Skala yang disebarkan pada responden merupakan skala dengan bentuk pertanyaan tertutup, namun di bagian data tambahan disusun dengan pertanyaan terbuka agar tidak menutup variasi jawaban responden. Skala ini menggunakan skala Likert yang telah dimodifikasi dengan empat pilihan jawaban untuk mengetahui kesesuaian pernyataan dalam skala dengan keadaan diri responden. Oleh karena itu, peneliti menyediakan empat pilihan jawaban yakni: (1) sangat tidak sesuai (STS); (2) tidak sesuai (TS); (3) sesuai (S); dan (4) sangat sesuai (SS). Responden diwajibkan untuk memilih salah satu dari alternatif jawaban yang tersedia.

Validitas yang diuji dari skala penelitian ini adalah validitas isi dan validitas konstrak. Pengujian validitas isi dilakukan dengan dua metode yaitu professional judgement dan uji coba bahasa terhadap individu yang memiliki kriteria mirip dengan responden penelitian. Sementara untuk uji validitas konstrak, peneliti melakukan uji coba dengan menyebarkan skala pada individu dengan karakteristik mirip responden penelitian untuk memperoleh data empirik. Data 
empirik dari responden diolah secara statistik dengan bantuan program Statistical Package for Social Science (SPSS) versi 15.0 hingga menghasilkan koefisien korelasi aitem total. Koefisien korelasi antar aitem akan digunakan untuk menilai validitas skala penelitian. Aitem dalam skala dinyatakan valid apabila memiliki nilai koefisien korelasi aitem total $>0,25$ (Azwar, 2012).

Pengukuran reliabilitas skala penelitian ini menggunakan metode single trial administration. Penghitungan reliabilitas skala menggunakan pendekatan konsistensi internal dengan formula Alpha Cronbach dua belahan. Koefisien reliabilitas skala penelitian yang bernilai $>0,60$ sudah tergolong tinggi, sehingga memadai untuk digunakan dalam pengukuran (Arikunto, 2006).

Peneliti melakukan uji validitas isi dengan metode professional judgement bersama tiga orang dosen. Berdasarkan uji coba bahasa bersama enam orang individu yang memiliki karakteristik sesuai dengan responden penelitian, diperoleh hasil berupa opini yang menyatakan bahwa bahasa dalam pernyataan skala cukup mudah untuk dipahami, namun satu orang responden bingung dengan arti kata "intimasi" di bagian data tambahan. Berdasarkan hasil uji coba, peneliti mengganti kata "intimasi" dengan kata "keintiman". Pada kalimat pernyataan skala, peneliti tidak melakukan perubahan apapun. Uji validitas konstrak dan reliabilitas alat ukur dilakukan dengan cara menyebarkan skala penelitian kepada 42 orang wanita Bali yang memiliki kriteria sesuai dengan responden penelitian. Semua responden uji coba alat ukur tersebar di Kelurahan Padangsambian Kecamatan Denpasar Barat. Uji coba alat ukur penelitian dilakukan selama 1 minggu pada pertengahan bulan Februari 2014.

Setelah melewati proses uji coba, skala harga diri menghasilkan 27 aitem valid dari 54 aitem yang diujicobakan. Rentang koefisien korelasi antar aitem berkisar antara 0,259 sampai dengan 0,707 pada aitem valid, dengan koefisien reliabilitas sebesar 0,883. Sementara skala pengambilan keputusan untuk kawin memiliki 16 aitem valid dari 34 aitem yang diujicobakan. Rentang koefisien korelasi antar aitem berkisar antara 0,295 sampai dengan 0,640 pada 16 aitem valid, dengan koefisien reliabilitas sebesar 0,824 .

\section{Metode pengumpulan data}

Pada penelitian ini, peneliti menggunakan skala sebagai alat untuk mengumpulkan data dan informasi dari responden secara langsung. Alat yang digunakan adalah skala yang telah dirancang sedemikian rupa oleh peneliti untuk merekam data tentang keadaan yang dialami oleh responden (Bungin, 2008).

Terdapat dua skala yang digunakan oleh peneliti, yakni skala harga diri dan skala pengambilan keputusan untuk kawin. Pada setiap skala di bagian identitas responden, responden diminta untuk mencantumkan nama, usia, pendidikan terakhir, dan urutan kelahiran. Pada bagian data tambahan, responden diminta untuk memilih salah satu dari alternatif pilihan yang ada terkait dengan alasan responden memilih kawin. Selain itu, responden juga diminta memberikan ranking terkait kepuasan perkawinan yang dijalani, serta mengutarakan alasan dibalik angka yang diberikan pada ranking kepuasan perkawinan. Skala juga dilengkapi dengan penjelasan berupa tata cara pengisian. Di akhir skala, peneliti mencantumkan identitas diri, kontak yang dapat dihubungi, serta memberikan jaminan bahwa kerahasiaan segala respon dan identitas responden akan dijaga dari pihak yang tidak berkepentingan.

\section{Analisa data}

Peneliti melakukan analisis korelasi Pearson Product Moment, regresi linear sederhana, dan kategorisasi jenjang ordinal untuk data dari dua variabel utama. Analisis korelasi Pearson Product Moment bertujuan untuk melihat arah dan kekuatan hubungan antara variabel bebas dengan variabel tergantung. Sedangkan analisis regresi linear sederhana bertujuan untuk menghitung varians yang terjadi pada variabel tergantung, serta memprediksi perubahan nilai variabel tergantung apabila nilai variabel bebas dimanipulasi (Sugiyono, 2013).

Peneliti juga akan melakukan interpretasi skor dari data penelitian. Data penelitian dikategorikan berdasarkan skor total skala masing-masing responden. Kategori skor akan dibagi menjadi lima jenjang yang berbeda. Penentuan kategorisasi skor skala dilakukan dengan menggunakan nilai mean dan standar deviasi teoretik. Untuk skor pada skala harga diri dan skala pengambilan keputusan untuk kawin dilakukan kategorisasi jenjang ordinal dengan batasan skor pada masing-masing kategori dapat ditentukan dengan rumus penghitungan sebagai berikut:

Tabel 1.

Rumus Kategorisasi Jenjang Ordinal Lima Daerah

\begin{tabular}{cc}
\hline Rumus & Kategori \\
\hline$\mu \leq-1,8 \sigma$ & Sangat rendah \\
$-1,8 \sigma<\mu \leq-0,6 \sigma$ & Rendah \\
$-0,6 \sigma<\mu \leq+0,6 \sigma$ & Sedang \\
$+0,6 \sigma<\mu \leq+1,8 \sigma$ & Tinggi \\
$+1,8 \sigma<\mu$ & Sangat tinggi \\
\hline
\end{tabular}

Pada data tingkat pendidikan dan urutan kelahiran, peneliti melakukan analisis tambahan berupa uji beda yaitu one-way ANOVA yang bertujuan untuk mengetahui apakah terdapat perbedaan pada mean skor variabel pengambilan keputusan untuk kawin apabila dilihat dari tingkat pendidikan dan urutan kelahiran responden. Pada data alasan melakukan perkawinan dan alasan kepuasan terhadap perkawinan, peneliti 
akan memaparkan temuan dalam bentuk deskriptif statistik. Sementara pada koefisien kepuasan perkawinan yang memiliki rentang nilai $1-10$, peneliti akan mengelompokkan nilai ke dalam tiga daerah pada satu kurva normal. Pengelompokkan dilakukan dengan berpatokan pada nilai mean dan standar deviasi teoretik menggunakan rumus kategorisasi jenjang ordinal yang dikemukakan oleh Azwar (2012). Rumus kategorisasi jenjang ordinal dimuat pada tabel di bawah ini:

Tabel 2.

\begin{tabular}{cc} 
Rumus Kategorisasi Jenjang Ordinal Tiga Daerah \\
\hline Rumus & Kategori \\
\hline$\mu \leq-1,0 \sigma$ & Rendah \\
$-1,0 \sigma<\mu \leq+1,0 \sigma$ & Sedang \\
$+1,0 \sigma<\mu$ & Tinggi \\
\hline & Sumber: Azwar (2012)
\end{tabular}

Metode analisis untuk data kualitatif yang digunakan adalah metode perbandingan tetap (Glaser \& Strauss dalam Moleong, 2004). Analisis yang dilakukan yaitu reduksi data, menyusun kategori, dan menyusun hipotesis kerja. Setelah melakukan analisis secara kualitatif untuk menemukan tematema dari jawaban responden, barulah data akan dianalisis lebih lanjut secara kuantitatif dalam bentuk deskriptif statistik.

\section{HASIL PENELITIAN}

Pada uji normalitas dengan analisis KolmogorovSmirnov Goodness of Fit Test dalam program SPSS 15.0, diketahui bahwa data skala harga diri dan data skala pengambilan keputusan untuk kawin berdistribusi normal. Sedangkan pada uji linearitas dengan analisis Test for Linearity Compare Means dalam program SPSS 15.0, diperoleh hasil bahwa antara variabel harga diri dan pengambilan keputusan untuk kawin memiliki hubungan yang linear.

Berdasarkan pengumpulan data dari 196 responden penelitian, diperoleh hasil bahwa sebagian besar responden berusia 40 tahun $(10,7 \%)$. Sebagian besar responden adalah anak tengah (49\%), sebanyak 26\% adalah anak sulung, 22,4\% adalah anak bungsu, dan 2,6\% adalah anak tunggal. Berdasarkan tingkat pendidikannya, responden dapat digolongkan ke dalam enam kelompok yaitu 52,6\% adalah lulusan Sekolah Menengah Atas/sederajat, lulusan Sekolah Menengah Pertama/sederajat sebesar 19,4\%, lulusan Strata Satu sebanyak $12,8 \%$, lulusan diploma sebesar $11,7 \%$, lulusan Sekolah Dasar sebanyak 2,0\%, serta lulusan Strata Dua sebesar $1,5 \%$.

Dalam hal kepuasan terhadap perkawinan yang dibina, 68,37\% responden berada pada golongan kepuasan tinggi. Di urutan kedua, sebanyak 30,10\% responden berada pada golongan kepuasan sedang. Sisanya yaitu sebesar $1,53 \%$ responden berada pada golongan kepuasan rendah.
Berdasarkan alasan merasa puas atau kurang puas dengan perkawinan yang dibina, ditemukan bahwa faktor suami menempati persentase tertinggi yaitu sebanyak $39,8 \%$. Kemudian sebanyak $25 \%$ responden menyatakan faktor anak, $6,6 \%$ responden menyebutkan faktor ekonomi, sebanyak $4,1 \%$ responden menyatakan faktor lingkungan, dan sisanya sebanyak $24,5 \%$ responden memberikan jawaban berupa perpaduan dari keempat faktor yang ada.

Sementara pada alasan melangsungkan perkawinan, sebagian besar responden menyatakan hubungan saling mendukung dengan pasangan sebagai alasan melangsungkan perkawinan. Deskripsi alasan perkawinan responden secara lengkap diuraikan pada tabel berikut:

Tabel 3.

Frekuensi Alasan Melakukan Perkawinan

\begin{tabular}{|c|c|}
\hline Alasan & Persentase \\
\hline rasa persahabatan dengan pasangan & $7,7 \%$ \\
\hline hubungan yang saling mendukung dengan pasangan & $40,3 \%$ \\
\hline ingin berbagi peran sebagai orangtua & $8,2 \%$ \\
\hline hamil & $13,8 \%$ \\
\hline pemberontakan melawan orangtua & $1,0 \%$ \\
\hline mencari kebebasan/kemandirian & $2,0 \%$ \\
\hline pelarian dari hubungan sebelumnya & $0,5 \%$ \\
\hline cinta kasih dan keintiman & $23,5 \%$ \\
\hline paksaan dari keluarga/lingkungan & $1,0 \%$ \\
\hline lain-lain & $2,0 \%$ \\
\hline
\end{tabular}

Pada kategorisasi jenjang ordinal skor harga diri dan pengambilan keputusan untuk kawin diperoleh hasil sebagai berikut:

Tabel 4.

Kategorisasi Skor Harga Diri

\begin{tabular}{ccc}
\multicolumn{3}{c}{ Kategorisasi Skor Harga Diri } \\
\hline Rentang nilai & Kategori & Persentase \\
\hline$\leq 43,20$ & Sangat rendah & $0 \%$ \\
43,21 sd. 59,40 & Rendah & $0 \%$ \\
59,41 sd. 75,60 & Sedang & $6,12 \%$ \\
75,61 sd. 91,80 & Tinggi & $68,88 \%$ \\
$>91,80$ & Sangat tinggi & $25,00 \%$ \\
\hline
\end{tabular}

Berdasarkan kategorisasi yang sudah dilakukan, sebagian besar yaitu $68,88 \%$ responden berada pada rentang skor harga diri tinggi. Sedangkan persentase terkecil terdapat pada kategori skor harga diri sangat rendah dan rendah yaitu $0 \%$ dari total keseluruhan responden. Hal ini berarti sebagian besar responden memberikan evaluasi yang positif terhadap diri sendiri mengenai kompetensi diri, keberhargaan diri, serta penghormatan pada nilai pribadi yang dianut. 
Tabel 5. Kategorisasi Skor Pengambilan Keputusan Untuk Kawin

\begin{tabular}{ccc}
\hline Rentang nilai & Kategori & Persentase \\
\hline$\leq 25,60$ & Sangat kurang baik & $0 \%$ \\
25,61 sd. 35,20 & Kurang baik & $0 \%$ \\
35,21 sd. 44,80 & Culkup bailk & $13,27 \%$ \\
44,81 sd. 54,40 & Baik & $78,57 \%$ \\
$>54,40$ & Sangat baik & $8,16 \%$ \\
\hline
\end{tabular}

Berdasarkan kategorisasi yang sudah dilakukan, sebagian besar yaitu 78,57\% responden berada pada rentang skor pengambilan keputusan kawin yang baik. Sedangkan persentase terkecil terdapat pada kategori skor pengambilan keputusan kawin yang sangat kurang baik dan kurang baik yaitu, 0\% dari total keseluruhan responden. Hal ini berarti sebagian besar responden menjalani rangkaian pengambilan keputusan yang benar untuk kawin dengan mempertimbangkan aspek hasil yang diharapkan, mencari informasi dan melakukan evaluasi, serta memiliki kompetensi untuk menentukan keputusan.

Pada uji hipotesis, digunakan teknik korelasi Pearson Product Moment dengan taraf signifikansi 5\%, diperoleh hasil bahwa terdapat hubungan positif yang signifikan antara harga diri dengan pengambilan keputusan untuk kawin pada wanita Bali usia dewasa awal $(r=0,723 ; p=0,000)$. Pada uji regresi linear sederhana, diperoleh koefisien determinasi (R2) sebesar 0,523 yang berarti sebesar 52,3\% variabel pengambilan keputusan untuk kawin dapat dijelaskan oleh variabel harga diri, dan sisanya sebesar $47,7 \%$ dijelaskan oleh faktor lain yang tidak menjadi fokus kajian dalam penelitian ini.

Pada uji regresi linear sederhana, diketahui bahwa model regresi adalah valid, sehingga model regresi dapat digunakan untuk memprediksi nilai variabel tergantung $(\mathrm{F}=212,520 ; \mathrm{p}=0,000)$. Pada pengujian persamaan garis regresi, diperoleh nilai konstanta pada variabel harga diri yang dapat digunakan untuk memprediksi varians yang terjadi pada variabel pengambilan keputusan untuk kawin. Persamaan regresi yang digunakan adalah $\mathrm{Y}=11,577+0,427 \mathrm{X}$. Koefisien regresi bernilai positif yaitu sebesar 0,427 yang berarti setiap penambahan 1 poin nilai harga diri, maka akan meningkatkan nilai pengambilan keputusan untuk kawin sebesar 0,427 poin. Persamaan garis regresi kemudian diuji validitasnya dalam memprediksi variabel pengambilan keputusan untuk kawin. Koefisien regresi yang diperoleh dinyatakan valid $(\mathrm{t}=14,578$; $\mathrm{p}=0,000)$ dan konstanta regresi yang diperoleh juga dinyatakan valid $(\mathrm{t}=4,553 ; \mathrm{p}=0,000)$. Berdasarkan hasil pengujian persamaan garis regresi, maka dapat diartikan bahwa persamaan regresi dalam penelitian ini adalah valid, sehingga diantara variabel harga diri dan variabel pengambilan keputusan untuk kawin diyakini memiliki hubungan fungsional sebab akibat.

Uji beda pada data tambahan dilakukan dengan jumlah sampel 189 orang. Uji asumsi normalitas pada data tambahan dilakukan dengan analisis Kolmogorov-Smirnov
Goodness of Fit Test, sementara uji homogenitas menggunakan analisis Levene test. Berdasarkan hasil uji asumsi, sebaran data skala pengambilan keputusan untuk kawin bersifat normal. Sementara pada uji homogenitas, varians populasi berdasarkan tingkat pendidikan dan urutan kelahiran adalah homogen. Melalui uji one-way ANOVA, diperoleh hasil bahwa tidak terdapat perbedaan yang signifikan pada skor pengambilan keputusan untuk kawin apabila dikaji dari tingkat pendidikan $(\mathrm{F}=1,169 ; \mathrm{p}=0,323)$ maupun urutan kelahiran $(\mathrm{F}=0,601 ; \mathrm{p}=0,550)$.

\section{PEMBAHASAN DAN KESIMPULAN}

Berdasarkan hasil analisis Pearson Product Moment, maka dapat disimpulkan bahwa hipotesis dalam penelitian ini diterima. Sehingga dapat dikatakan bahwa terdapat hubungan antara harga diri dengan pengambilan keputusan untuk kawin pada wanita Bali usia dewasa awal, dengan koefisien korelasi sebesar 0,723. Koefisien korelasi yang bernilai antara 0,600 0,799 dapat digolongkan sebagai korelasi yang kuat (Sugiyono, 2013).

Nilai koefisien determinasi (R2) sebesar 0,523 yang berarti variabel harga diri mampu menjelaskan varians yang terjadi pada variabel pengambilan keputusan untuk kawin sebanyak 52,3\%, sedangkan sisanya sebanyak $47,7 \%$ dapat dijelaskan oleh variabel lain yang tidak diteliti dalam penelitian ini. Menurut beberapa ahli, terdapat faktor-faktor lain yang berperan dalam pengambilan keputusan yang dilakukan oleh individu, yaitu faktor bakat, minat, sikap, kepribadian, aspirasi dan pengetahuan sekolah, intelegensi, urutan kelahiran, kelompok primer, serta kelompok sekunder (Sukardi, 2004); efikasi diri, kepercayaan diri, dan budaya (Wolfe \& Betz, 2004); emosi, kesanggupan, tuntutan orangtua atau keluarga, dan pengalaman (Gunarsa \& Gunarsa, 1995).

Nilai koefisien korelasi dan koefisien determinasi yang menunjukkan nilai positif dapat diartikan bahwa terdapat hubungan yang searah antara variabel harga diri dengan variabel pengambilan keputusan untuk kawin. Hubungan searah dapat diartikan sebagai kenaikan atau penurunan nilai secara linear antar kedua variabel. Apabila terjadi kenaikan pada nilai harga diri, maka pada nilai pengambilan keputusan untuk kawin juga akan terjadi peningkatan dan begitu pula sebaliknya. Apabila terjadi penurunan pada nilai harga diri, maka pada nilai pengambilan keputusan untuk kawin juga akan terjadi penurunan.

Pada hasil pengujian model regresi diperoleh hasil bahwa model regresi adalah valid, sehingga model regresi dapat digunakan untuk memprediksi nilai variabel tergantung. Persamaan regresi yang digunakan adalah $\mathrm{Y}=11,577+0,427 \mathrm{X}$. Koefisien regresi bernilai positif yaitu sebesar 0,427 yang berarti setiap penambahan 1 poin nilai harga diri, maka akan meningkatkan nilai pengambilan keputusan untuk kawin 
sebesar 0,427 poin. Koefisien regresi dan konstanta regresi yang diperoleh dalam penelitian ini adalah valid. Sementara pada pengujian persamaan garis regresi, diperoleh hasil bahwa persamaan regresi yang digunakan adalah valid, yang berarti diantara variabel harga diri dan variabel pengambilan keputusan untuk kawin diyakini memiliki hubungan fungsional sebab akibat.

Apabila melihat hipotesis dan berdasarkan hasil uji statistik yang dilakukan, maka diperoleh hasil bahwa hipotesis yang diajukan dalam penelitian ini dapat diterima atau dengan kata lain, terdapat hubungan positif yang signifikan antara harga diri dengan pengambilan keputusan untuk kawin pada wanita Bali usia dewasa awal. Hal ini sejalan dengan beberapa penelitian sebelumnya yang menemukan fakta bahwa terdapat hubungan yang signifikan antara harga diri dengan pengambilan keputusan. Menurut Lazarus (1991), individu dengan harga diri yang tinggi cederung lebih baik dalam usaha memperoleh informasi terkait dengan isu pengambilan keputusan yang akan dilakukan dan mengembangkan strategi untuk membantu diri menentukan keputusan, serta mengatur sumber daya yang sudah dimiliki dengan lebih efektif. Sumber daya internal termasuk kepercayaan diri individu pada kemampuan yang dimiliki. Semakin individu percaya pada kemampuan yang dimiliki di dalam diri, maka akan semakin baik hasil dari sebuah usaha yang individu lakukan (Branden, 1992).

Kegiatan dasar yang sangat penting pada pengambilan keputusan adalah pengumpulan informasi mengenai situasi dimana sebuah keputusan dapat dibuat (Supranto, 1998), sehingga sebelum menentukan suatu keputusan sangat penting bagi individu untuk memiliki informasi dan pengetahuan tentang situasi dan persoalan yang dihadapi. Individu dengan harga diri yang tinggi cenderung membuat keputusan dengan lebih baik karena berusaha menemukan lebih banyak informasi, mencari lebih banyak pilihan alternatif, dan mempertimbangkan dengan lebih seksama setiap konsekuensi yang menyertai alternatif pilihan yang ada (Ramanigopal, 2008). Individu dengan harga diri yang tinggi cenderung dapat membuat keputusan dengan baik karena memiliki kepercayaan pada kemampuan diri sendiri (Prayor \& Smith; Mann, Beswick, Allouache, \& Ivey dalam Ramanigopal, 2008). Individu dengan harga diri dan kepercayaan diri yang tinggi, serta memiliki keyakinan pada kemampuan diri dalam hal melihat dan mempertimbangkan berbagai alternatif pemecahan masalah akan mampu mengambil keputusan dengan baik dan tepat tanpa banyak tergantung pada pendapat individu lain (Irwanto dalam Listyaningrum, 2007).

Perkawinan merupakan salah satu tugas pada tahap perkembangan usia dewasa awal (Papalia, Olds, \& Feldman, 2009; Santrock, 2002). Perkawinan adalah sebuah kegiatan yang memiliki risiko konflik dan tantangan (Sadarjoen, 2005).
Setiap pengambilan keputusan melibatkan perilaku berani mengambil risiko karena sebuah keputusan akan meninggalkan konsekuensi tertentu (Yates, 1994). Namun individu dengan tingkat harga diri yang tinggi akan cenderung lebih berani mengambil keputusan yang berisiko (Leary \& Downs dalam Wray \& Stone, 2005).

Begitu pula dengan wanita Bali yang hendak melangsungkan perkawinan perlu mengumpulkan informasiinformasi penting terkait perkawinan. Wanita Bali masa kini telah dimungkinkan untuk mengambil inisiatif lebih dahulu dalam hal merencanakan perkawinan, namun dengan tetap mempertimbangkan nilai etika yang berlaku (Atmaja, 2008). Perkembangan kesetaraan gender dalam hal perkawinan membuat wanita Bali perlu melakukan usaha agar memiliki pengetahuan mengenai dinamika perkawinan, karena pascaperkawinan akan terjadi perubahan hak dan kewajiban yang harus dilaksanakan oleh wanita (Suryani, 2003; Windia dkk, 2009; Sudantra, Narendra, \& Sudiana, 2011). Perubahan hak dan kewajiban wanita pascaperkawinan akan tergantung pada bentuk perkawinan yang dijalani.

Perkawinan adalah suatu hal yang lazim dilakukan wanita pada usia dewasa awal, namun terkait dengan faktor budaya pada masyarakat Bali yang hingga kini masih lekat terpengaruh oleh budaya patriarki, terdapat stereotype tentang perkawinan yang menganggap bahwa wanita bersifat pasif, siap, dan menunggu laki-laki bertindak. Wanita dapat mengambil inisiatif terlebih dahulu, namun tetap harus menunggu pihak laki-laki untuk eksekusi akhir. Keinginan untuk melangsungkan perkawinan dapat saja muncul terlebih dahulu pada benak wanita, namun apabila wanita yang datang terlebih dahulu menawarkan diri pada laki-laki, maka hal ini akan dianggap memalukan dan memilukan bagi wanita itu sendiri (Atmaja, 2008). Jeter (2002) mengungkapkan, perkawinan amat sangat terikat dengan budaya. Oleh sebab itu, wanita Bali dengan urutan kelahiran tertentu dengan keunikan karakter masing-masing dapat saja berbeda ketika membuat suatu keputusan, namun terdapat satu kesamaan yaitu ruang lingkup dan pengaruh budaya tempat wanita bersosialisasi. Keputusan untuk melakukan perkawinan tidak hanya tentang wanita itu sendiri saja, namun juga terkait dengan suku bangsa, latar belakang pendidikan, status sosial ekonomi, dan budaya (Meinarno, Widianto, \& Halida, 2011).

Pengaruh lingkungan sosial dalam budaya patriarki dan kolektivis menuntun wanita untuk memilah dan memilih alternatif terbaik bagi diri dan individu terdekat. Hal ini menempatkan pilihan untuk kawin sebagai salah satu alternatif yang mungkin ditempuh oleh wanita sebagai pilihan untuk memenuhi tugas perkembangan dan menghindari prasangka dari lingkungan sosial. Di sisi lain, individu dengan tingkat harga diri yang tinggi cenderung akan membuat keputusan sendiri daripada menggantungkan keputusan pada pilihan individu lain (Blanchard-Fields dalam Gayer, 2013), sehingga 
dapat disimpulkan berdasarkan hasil penelitian dan teori terkait bahwa wanita dengan tingkat harga diri yang tinggi akan cenderung merasa yakin dengan kemampuan yang dimiliki, mengumpulkan lebih banyak informasi sebelum membuat keputusan, serta mempertimbangkan dengan lebih cermat hasil yang mungkin akan diperoleh di kemudian hari setelah mengambil keputusan yang dalam hal ini adalah keputusan untuk kawin.

Merujuk pada skor skala pengambilan keputusan untuk kawin yang dihasilkan pada penelitian ini, ternyata ratarata skor pengambilan keputusan untuk kawin tidak berbeda secara signifikan pada responden dengan latar belakang pendidikan SMP, SMA, Diploma, dan Strata satu. Menurut Morissan (dalam Dwi Putri, 2012), perilaku manusia adalah hasil bentukan dari proses belajar yang akan memberikan pengetahuan. Pengetahuan erat dihubungkan dengan jenjang pendidikan formal yang ditempuh individu. Diasumsikan bahwa semakin tinggi jenjang pendidikan individu, maka akan semakin banyak pengetahuan yang dimiliki. Namun pengetahun tidak hanya dapat diperoleh melalui pendidikan formal saja, tetapi juga dapat melalui pendidikan non formal (Dwi Putri, 2012). Sebagian besar responden berada pada kategori pengambilan keputusan kawin yang baik. Responden memiliki indikasi telah melakukan pencarian informasi, melakukan evaluasi, memiliki kemampuan mengambil keputusan, dan mengetahui tujuan yang ingin dicapai dalam perkawinan. Tidak ada perbedaan yang signifikan pada mean skor pengambilan keputusan untuk kawin, dapat disebabkan karena responden memperoleh informasi mengenai perkawinan tidak hanya melalui pendidikan formal, tetapi juga melalui pencarian informasi secara sinformal.

Selain itu, rata-rata skor pengambilan keputusan untuk kawin tidak berbeda secara signifikan pada responden yang merupakan anak sulung, anak tengah, maupun anak bungsu. Tidak ada perbedaan rata-rata skor pengambilan keputusan untuk kawin kemungkinan disebabkan karena pengaruh faktor lain diluar diri individu seperti keluarga, budaya, dan pengalaman yang diperoleh. Seperti yang diungkapkan oleh Feist dan Feist (2009), bahwa individu memiliki kebebasan untuk mengubah hal yang sudah ditentukan karena adanya berbagai pengaruh dari dalam maupun luar diri (Feist \& Feist, 2009). Pengaruh faktor eksternal tidak dapat diabaikan pada perilaku individu. Pengaruh faktor eksternal juga dapat terjadi pada perilaku pengambilan keputusan untuk kawin, karena perkawinan berhubungan erat dengan budaya (Jeter, 2002; Matsumoto \& Juang, 2008; Meinarno, Widianto, \& Halida, 2011), dan budaya tempat individu bersosialisasi dapat mempengaruhi pengambilan keputusan yang dilakukan (Wolfe \& Betz, 2004). Penelitian kali ini tidak hanya memperoleh data yang diolah dengan analisis korelasi maupun komparasi, tetapi juga dengan analisis deskriptif. Berdasarkan data yang diperoleh, sebagian besar responden yaitu 40,30\% menyatakan bahwa hubungan yang saling mendukung dengan pasangan merupakan alasan responden melangsungkan perkawinan. Hubungan yang saling mendukung dengan pasangan merupakan isu penting dalam perkawinan. Perkawinan merupakan wadah legal untuk mengatur hubungan seksual dan melahirkan keturunan. Khusus bagi perkawinan dalam masyarakat adat Bali, salah satu tujuan utama perkawinan adalah untuk memiliki keturunan (Pudja dalam Windia dkk, 2009).

Dukungan dari pasangan dalam sebuah hubungan intim sangat penting bagi wanita, khususnya pada masa awal melahirkan (Bielinski-Blattmann, Lemola, Jaussi, Stadlmayr, \& Grob, 2009). Hubungan yang saling mendukung dengan pasangan menghindarkan wanita dari kecenderungan merasa depresi (post-partum depression) pada masa awal menjadi orangtua (Boyce \& Hickey, 2005). Wanita yang menerima dukungan dari pasangan mengembangkan subjective wellbeing dengan lebih baik, memiliki penyesuaian diri yang lebih baik pada kehidupan sebagai ibu, serta memiliki tingkat gejala depresi yang lebih rendah (Patel, Rodrigues, \& DeSouza, 2002).

Pada era globabalisasi, selain bekerja di ranah domestik rumah tangga dan mengurus anak, wanita juga berperan sebagai pekerja yang mencari nafkah di luar rumah (Eisenstein dalam Beydoun, 2012). Bagi wanita Bali, peran yang dijalani tidak hanya bekerja ataupun hanya sebagai ibu, namun lebih kompleks dengan aturan bermasyarakat dalam bentuk ngayah dan ngoopin melalui aktivitas upacara agama demi menjaga hubungan baik dengan keluarga besar (Suryani, 2003). Selain itu, tuntutan kebutuhan hidup yang semakin tinggi juga menuntut wanita untuk mampu membantu menghasilkan nafkah untuk keluarga (Winarti, Santosa, Darmawan, \& Kurniawati, 2008).

Wanita yang berprofesi sebagai pekerja di luar rumah dan pengurus keluarga rentan mengalami konflik pekerjaankeluarga. Wanita diharapkan dapat menyelesaikan tugas-tugas pekerjaan, namun juga tidak boleh melupakan keluarga dan rumah tangga. Peran ganda yang dilakoni secara terusmenerus membuat wanita cenderung rentan mengalami stres (Indriyani, 2009). Penting bagi wanita untuk mendapatkan dukungan agar mampu bergulat dengan kewajiban harian. Pasangan adalah salah satu sumber dukungan yang meningkatkan kemampuan wanita dalam beradaptasi dengan tekanan di lingkungan kerja (Turner, 2009). Adanya hubungan yang saling mendukung antara pasangan dengan berbagi kesempatan untuk mengembangkan diri, karir, dan prestasi masing-masing akan menuntun ke arah perkawinan yang sukses (Olson \& DeFrain, 2003).

Hubungan intim seperti perkawinan tidak dapat lepas dari isu kepuasan perkawinan yang dipersepsikan oleh pasangan yang membina hubungan. Kepuasan perkawinan 
adalah suatu perasaan positif yang bermakna lebih luas dari dari sekedar kenikmatan, kesenangan, dan kesukaan yang dirasakan oleh pasangan dalam perkawinan berdasarkan evaluasi kognitif (Lestari, 2012). Berdasarkan data yang diperoleh, mayoritas responden $(68,37 \%)$ berada pada golongan kepuasan perkawinan tinggi dan sebanyak 78,57\% memiliki rata-rata skor pengambilan keputusan untuk kawin yang baik. Selaras dengan pendapat Manullang (1994) yang menyatakan bahwa sebuah keputusan yang baik adalah keputusan yang mampu membawa kesenangan, kebahagiaan, serta kepuasan di hari depan bagi individu yang membuat keputusan. Hal ini semakin mempertegas bahwa pengambilan keputusan untuk kawin yang dilakukan oleh wanita Bali adalah memang sebuah keputusan yang baik karena membawa rasa puas bagi wanita pada perkawinan yang dibina.

Berdasarkan data mengenai kepuasan perkawinan, diperoleh hasil bahwa mayoritas responden (39,80\%) menyatakan bahwa suami adalah alasan untuk merasa puas maupun kurang puas dengan perkawinan yang dibina. Sementara $25 \%$ menyatakan bahwa anak adalah alasan utama untuk merasa puasan atau kurang puas dengan perkawinan yang dibina. Sisanya yaitu $(6,60 \%)$ berpendapat bahwa faktor ekonomi adalah alasan utama, dan 4,10\% menyatakan faktor lingkungan sebagai alasan utama merasa puas atau kurang puas dengan perkawinan yang dijalani. Hasil yang diperoleh selaras dengan penemuan Putra, Wiraswati, Herdiyanto, dan Tobing (2013) yang mengatakan bahwa kebahagiaan perkawinan wanita Bali dilatarbelakangi oleh tiga faktor utama yaitu anak, suami, serta keluarga dan lingkungan sosial di sekitar. Namun dalam penelitian ini ditemukan satu faktor tambahan yaitu ekonomi.

Keempat alasan yang diungkapkan oleh responden dalam penelitian ini bukanlah tidak beralasan. Menurut Suryani (2003), suami menjadi alasan utama kepuasan dan ketidakpuasan wanita pada perkawinan karena dalam sebuah perkawinan, istri dan suami adalah tiang penopang keluarga serta pengayom bagi anak-anak. Wanita yang memutuskan untuk hidup melajang, tidak memiliki suami dan anak membuat wanita merasa kesepian dan sendiri menghadapi masalah di hari tua. Ekonomi yang mapan namun tanpa disertai dengan kasih sayang dari individu terdekat dirasa belum mampu untuk memberi wanita kebahagiaan dalam perkawinan. Sebaliknya, dengan adanya suami yang memberikan kasih sayang dan perhatian cenderung membuat wanita merasa aman dan berbahagia. Jeter (2002) mengatakan bahwa tidak ada penelitian yang menemukan hasil bahwa uang membuat kehidupan perkawinan berjalan lebih mulus, namun memang kemiskinan yang teramat sangat dapat menimbulkan masalah besar dalam perkawinan, sehingga keadaan ekonomi harus disikapi dengan bijak oleh pasangan yang membina perkawinan.
Kehadiran anak dalam perkawinan tidak kalah penting bagi wanita Bali. Apabila dilihat, masyarakat adat Bali sebagian besar menganut agama Hindu (Kurniawati, 2009). Agama Hindu memandang anak, khususnya anak laki-laki sebagai penerus keturunan untuk melanjutkan hak dan kewajiban orangtua, serta kelahiran anak berperan untuk menyelamatkan roh leluhur dari kesengsaraan (Pudja \& Sudarta dalam Windia dkk, 2009). Pada penelitian yang dilakukan oleh Putra, Wiraswati, Herdiyanto dan Tobing (2013), wanita Bali yang menjadi responden penelitian menempatkan anak sebagai alasan utama wanita merasa bahagia dan puas dengan perkawinan yang dibina. Oleh karena itu, kehadiran anak sebagai penerus dalam keluarga memiliki arti penting bagi wanita Bali dalam perkawinan yang dijalani.

Sebagian besar masyarakat di dunia menerapkan garis keturunan patrilineal pada sistem kekerabatan yang dianut (Murdock dalam Meinarno, Widianto, \& Halida, 2011). Keadaan lingkungan keluarga yang harmonis menjadi perhatian dalam kepuasan perkawinan dari sudut pandang wanita. Hal ini disebabkan karena pascaperkawinan, secara umum, wanita akan masuk ke dalam rumpun keluarga suami. Sosialisasi antara wanita dengan keluarga suami, baik secara langsung karena tinggal serumah ataupun secara tidak langsung karena tinggal terpisah rumah akan terjadi secara terus-menerus sepanjang hidup, bersamaan dengan berbagai institusi lain diluar keluarga (Susilastuti dalam Anissa \& Handayani, 2012).

Menurut Suryani (2003), wanita Bali terbiasa menjalani peran ganda yang meliputi peran dalam rumah tangga, bekerja mencari nafkah, dan bermasyarakat dalam kehidupan sehari-hari dengan menerapkan konsep menyama braya yang memahami bahwa semua manusia adalah bersaudara, sehingga sering diterapkan dalam perilaku tolongmenolong ketika anggota keluarga lain sedang melaksanakan upacara keagamaan atau kegiatan sosial (Purawati, 2011). Apabila hubungan dengan anggota keluarga lain selain keluarga inti (suami dan anak) tidak harmonis, maka wanita akan merasa kurang nyaman dengan kehidupan perkawinan yang dibina karena interaksi dengan anggota keluarga suami akan terjadi secara terus-menerus sejak wanita resmi dipersunting oleh suami.

Saran yang dapat diberikan yaitu, bagi wanita Bali yang hendak melangsungkan perkawinan, diharapkan mencari informasi sebanyak mungkin mengenai dinamika kehidupan perkawinan agar dapat mengambil suatu keputusan yang matang untuk kawin. Bagi wanita Bali yang telah membina perkawinan, diharapkan mempertahankan jalinan relasi harmonis dengan pasangan agar perasaan puas terhadap perkawinan yang dibina dapat semakin meningkat. Menjaga kehidupan perkawinan agar tetap dalam kondisi yang harmonis dan saling mendukung, sehingga wanita memperoleh kesempatan yang semakin besar untuk 
mengembangkan harga diri ke arah yang positif. Membagi peran dengan pasangan dalam hal menentukan keputusan dalam perkawinan agar wanita memperoleh kesempatan untuk semakin meningkatkan harga diri.

Sementara bagi peneliti selanjutnya, diharapkan memperbesar jumlah responden penelitian dan memperluas daerah pengumpulan data. Meneliti variabel lain seperti minat, bakat, sikap, kepribadian, intelegensi, efikasi diri, pengaruh keluarga dan teman sebaya yang tidak menjadi fokus kajian dalam penelitian ini, namun secara teori turut berperan memberikan pengaruh pada pengambilan keputusan agar memperoleh data yang komprehensif. Menggunakan skala pengukuran variabel pengambilan keputusan untuk kawin yang melibatkan unsur budaya dalam penyusunan aitem skala terkait dengan pentingnya kepekaan alat ukur dalam mengukur variabel dengan latarbelakang budaya. Mempertimbangkan bentuk-bentuk perkawinan dalam masyarakat adat Bali untuk mengkaji variabel harga diri dan pengambilan keputusan untuk kawin yang dilakukan oleh wanita Bali. Melakukan penelitian lanjutan dengan pendekatan kualitatif untuk memperoleh data yang mendalam mengenai alur proses pengambilan keputusan untuk kawin yang dialami oleh wanita Bali.

\section{DAFTAR PUSTAKA}

Anissa, N., \& Handayani, A. (2012). Hubungan antara konsep diri dan kematangan emosi dengan penyesuaian diri istri yang tinggal bersama keluarga suami. Jurnal Psikologi Pitutur, 1, 57-67.

Arikunto, S. (2006). Prosedur penelitian suatu pendekatan praktik. Jakarta: PT Remaja Cipta.

Atmaja, J. (2008). Bias gender perkawinan terlarang pada masyarakat Bali. Denpasar: Udayana University Press.

Atmosudirjo, S. P. (1984). Beberapa pandangan umum tentang pengambilan keputusan (decision making). Jakarta: Ghalia Indonesia.

Azwar, S. (2012). Penyusunan skala psikologi (ed.2). Yogyakarta: Pustaka Pelajar.

Beydoun, L. (2012). Obstacles to work opportunities and community organizing among lebanese women in Sierra Leone. International Journal of Business and Social Science, 3, 250-260.

Bielinski-Blattmann, D., Lemola, S., Jaussi, C., Stadlmayr, W., \& Grob, A. (2009). Postpartum depressive symptoms in the first 17 months after childbirth: The impact of an emotionally supportive partnership. International Journal Public Health, 54, 333-339. doi: 10.1007/s00038-009-00564.

Boyce, P., \& Hickey, A. (2005). Psychosocial risk factors to major depression after childbirth. Soc Psychiatry Psychiatr Epidemiol. 60, 605-612.

Branden, N. (1992). The power of self-esteem. Florida: Health Communications, Inc.
Branden, N. (1995). The six pillars of self-esteem: The definitive work on self-esteem by the leading pioneer in the field. New York: Bantam Books.

Bungin, B. (2008). Metodologi penelitian kuantitatif: Komunikasi, ekonomi, dan kebijakan publik serta ilmu-ilmu sosial lainnya. Jakarta: Kencana.

Commendador, K. (2007). The relationship between female adolescent self-esteem,decision making, and contraceptive behavior. Journal of the American Academy of Nurse Practitioners, 19, 614-623.

Dwi Putri, P. K. (2012). Pengaruh tingkat pendidikan, pengetahuan, sikap, dan terpaan iklan layanan masyarakat KB versi Shireen Sungkar dan Teuku Wisnu di TV terhadap perilaku $\mathrm{KB}$ pada wanita atau pria dalam usia subur. Jurnal Interaksi, 46-56.

Farruggia, S. P., Chen, C., Greenberger, E., Dmitrieva, J., \& Macek, P. (2004). Adolescent self-esteem in cross-cultural perspective testing measurement equivalence and a mediation model. Journal Of Cross-Cultural Psychology. 35, 719-733. doi: 10.1177/0022022104270114.

Feist, J., \& Feist, G. J. (2009). Theories of personality (ed.7). New York: McGraw-Hill.

Gayer, C. (2013). The effect of context and self-esteem on decision making competence and preferences for collaborative decision making in older adults. (Disertasi). University of Kentucky.

Ghufron, M. N., \& Risnawita, R. (2012). Teori-teori psikologi. Yogyakarta: Ar-ruzz Media.

Gunarsa, Y. S., \& Gunarsa, S. D. (1995). Psikologi praktis: anak, remaja, dan keluarga. Jakarta: Gunung Mulia.

Hague, P., \& Haris, P. (1995). Sampling dan statistik (Yulianto, Penerjemah). Jakarta: Pustaka Binaman Pressindo.

Huffman, K., Vernoy, M., Williams, B., \& Vernoy, J. (1991). Psychology in action (ed.2). New York: John Wiley \& Sons Inc.

Hurlock, E. B. (1980). Psikologi perkembangan suatu pendekatan sepanjang rentang kehidupan (ed.5) (Istiwidayanti \& Soedjarwo, Penerjemah). Jakarta: Erlangga.

Indriyani, A. (2009). Pengaruh konflik peran ganda dan stress kerja terhadap kinerja perawat wanita rumah sakit (studi pada rumah sakit Roemani Muhammadiyah Semarang). (Tesis tidak dipublikasikan). Universitas Diponegoro, Semarang.

Jeter, R. F. (2002). Intimate relationships. Dalam M. Biaggio, \& M. Hersen, Issues in the psychology of women (hlm. 173-198). New York: Kluwer Academic Publishers.

Kasim. (1989). Pengambilan keputusan yang efektif. Jakarta: PT. Citra Adi Perkasa.

Konrath, S. (2012). Self-esteem, culturally defined. Dalam Cultural sociology of mental illness: An A-to-Z guide. California: Sage Reference.

Kurniawati, D. (2009). Putri: Pemilihan identitas sebagai resistansi terhadap dominasi patriarki dan hukum adat Bali. (Tesis).Universitas Indonesia, Depok.

Lazarus, R. S. (1991). Emotion and adaptation. New York: Oxford University Press.

Lestari, S. (2012). Psikologi keluarga: Penanaman nilai dan penanganan konflik dalam keluarga (ed. 1). Jakarta: Kencana. 
Listyaningrum, M. M. (2007). Kemandirian dalam pengambilan keputusan pada remaja akhir ditinjau dari pengasuhan orangtua. (Skripsi tidak dipublikasikan). Universitas Katolik Soegijapranata, Semarang.

Mandei, J. R. (2010). Faktor penentu pilihan petani terhadap jenis usaha pengolahan nira di Desa Ranaan Lama Kecamatan Motoling Kabupaten Minahasa Selatan. ASE, 6, 9-16.

Manullang, M. (1994). Pedoman praktis pengambilan keputusan. Yogyakarta: BPFE.

Matsumoto, D., \& Juang, L. (2008). Culture and psychology (ed. 4). Belmont: Thomson Wadsworth.

Meinarno, E. A., Widianto, B., \& Halida, R. (2011). Manusia dalam kebudayaan dan masyarakat: Pandangan antropologi dan sosiologi (ed. 2). Jakarta: Salemba Humanika.

Moleong, L. J. (2004). Metodologi penelitian kualitatif (ed. revisi). Bandung: PT. Remaja Rosdakarya.

Nazir, M. (1988). Metode penelitian. Jakarta: Ghalia Indonesia.

Noor, J. (2011). Metodologi penelitian: Skripsi, tesis, disertasi dan karya ilmiah. Jakarta: Kencana.

Olson, D. H., \& DeFrain, J. (2003). Marriage and families: Intimacy, diversity, and strengths (ed.4). New York: McGraw-Hill.

Papalia, D. E., Olds, S. W., \& Feldman, R. D. (2009). Human development (ed.11). New York: McGraw-Hill.

Patel, V., Rodrigues, M., \& DeSouza, N. (2002). Gender, poverty, and postnatal depression: a study of mothers in Goa, India. Am J Psychiatry. 159, 43-47.

Peck, J. C. (1993). Wanita dan keluarga (Fransisca Dewi \& Fransisca L., Penerjemah). Yogyakarta: Kanisius.

Pemerintah Daerah Provinsi Bali. (2009). Peraturan Daerah Provinsi Bali Nomor 16 Tahun 2009 Tentang Rencana Tata Ruang Wilayah Provinsi Bali Tahun 2009-2029. 6.

Purawati, N. K. (2011). Pergulatan perempuan tukang suun Pasar Badung Kota Denpasar: Sebuah kajian budaya. (Tesis tidak dipublikasikan). Program Pascasarjana Universitas Udayana, Denpasar.

Putra, I. G., Wiraswati, A. S., Herdiyanto, Y. K., \& Tobing, D. H. (2013). What makes Balinese women with nyerod marriage happy?: An indigenous psychological approach. (naskah tidak dipublikasikan). Center for Health and Indigenous Psychology, Denpasar.

Putrawan, I. W., \& Sari, N. P. (2011). Statistik demografi dan sosial ekonomi rumah tangga Provinsi Bali 2011. Denpasar: Badan Pusat Statistik Provinsi Bali.

Ramanigopal, C. S. (2008). Self-esteem and decision making styles of school teachers. Journal of the Indian Academy of Applied Psychology, 34, 145-150.

Sadarjoen, S. S. (2005). Konflik marital: Pemahaman konseptual, aktual, dan alternatif solusinya. Bandung: PT. Refika Aditama.

Santrock, J. W. (2002). Life-span development (ed.5) (J. Damanik \& A. Chusairi, penerjemah). Jakarta: Erlangga.

Sarwono, S. W. (2006). Psikologi prasangka orang Indonesia. Jakarta: PT. RajaGrafindo Persada.

Sudantra , I. K., Narendra, K. G., \& Sudiana, I. N. (2011). Perkawinan menurut hukum adat Bali. Denpasar: Udayana University Press.

Sugiyono. (2013). Statistika untuk penelitian. Bandung: CV. Alfabeta.
Sukardi. (2004). Implikasi pengambilan keputusan. Jakarta: Bumi Aksara.

Supranto, J. (1998). Teknik pengambilan keputusan. Jakarta: Rineka Cipta.

Suryani, L. K. (2003). Perempuan Bali kini. Denpasar: PT. Offset BP Denpasar.

Tafarodi, R. W., \& Walters, P. (1999). Individualism-collectivism, life events, and self-esteem: A test of two trade-offs. European Journal of Social Psychology, 797-814.

Taylor, S. E., Peplau, L. A., \& Sears, D. O. (2009). Psikologi sosial (ed.12) (Tri Wibowo B.S., Penerjemah). Jakarta: Kencana.

Turner, S. D. (2009). Exploring resilience in the lives of women leaders in early childhood health, human services, and education. (Disertasi). Tersedia di pusat data ProQuest.

Winarti, M., Santosa, A. B., Darmawan, W., \& Kurniawati, Y. (2008). Pemberdayaan perempuan pada sektor industri kecil dalam mengatasi ekonomi keluarga. (naskah tidak dipublikasikan). Universitas Pendidikan Indonesia, Bandung.

Windia, W., Komalasari, G., Suartika, I., Sudantra, I., Dyatmikawati, P., Pemayun, C. A., et al. (2009). Perkawinan pada gelahang di Bali. Denpasar: Udayana University Press.

Wolfe, J. B., \& Betz, N. E. (2004, June). The relationship of attachment variables to career decision-making, selfefficacy, and fear of commitment.

Wray, L. D., \& Stone, E. R. (2005). The role of self-esteem and anxiety in decision making for self versus others in relationships. Journal of Behavioral Decision Making, 18, 125-144.

Yates, F. J. (1994). Risk-taking behavior. New York: John Wiley and Sons, Inc. 